\title{
O SUPREMO TRIBUNAL FEDERAL E OS ATOS INTERNA CORPORIS DO SENADO NO PROCESSO DE IMPEACHMENT: uma Análise do Ativismo Judicial no Ms. 34.441/Df
}

\section{Tito Lívio Cabral Renovato Silva}

Mestrando do Programa de Pós-Graduação em Ciências Sociais da Universidade Federal de Campina Grande (UFCG) - Campus I. Bacharel em Direito pela Universidade Estadual da Paraíba (UEPB). titoliviocabral@ig.com.br

\section{Resumo}

0 presente artigo tem por objetivo analisar a decisão monocrática na Medida Cautelar em Mandado de Segurança № 34.441/DF de relatoria do ministro do Supremo Tribunal Federal Teori Zavascki com base na Crítica Hermenêutica do Direito. Partindo do método hermenêutico, realizamos uma pesquisa bibliográfica e documental sobre o tema para coletar a referida decisão monocrática. Concluímos que a decisão monocrática do ministro Teori Zavascki foi tomada por um ato de vontade do julgador, que decidiu com base em argumentos políticos e não jurídicos, o que viola os pressupostos democráticos instituídos pela Constituição de 1988 e que os atos interna corporis do Senado Federal editados no processo de impeachment, como atos administrativos, podem ser apreciados pela jurisdição constitucional se violarem preceitos constitucionais.

\section{Palavras-chave:}

Ativismo judicial. Supremo Tribunal Federal. Crítica hermenêutica do Direito.

\section{THE SUPREME FEDERAL COURT AND THE INTERNA CORPORIS ACTS} OF THE SENATE IN THE IMPEACHMENT PROCESS:

an Analysis of Judicial Activism in Ms. 34,441 / DF

\section{Abstract}

The purpose of this article is to analyze the monocratic decision in the Precautionary Measure of Injuction No. 34.441 / DF of a report of the Minister of STF Teori Zavascki based on the Critique of Law Hermeneutics. Starting from the hermeneutic method, we carried out a bibliographical review on the subject and a documentary research to collect the mentioned 
monocratic decision. We conclude that the monocratic decision of Minister Teori Zavascki was taken by an act of will of the judge, who decided on the basis of political and non-legal arguments, which violates the democratic assumptions established by the 1988 Constitution and that the internal corporate acts of the Federal Senate Edited in the process of impeachment, as administrative acts, can be appreciated by the constitutional jurisdiction if they violate constitutional precepts.

\section{Keywords:}

Judicial activism. Supreme Federal Court. Critique of law hermeneutics.

Recebido em: 17/6/2017

Aceito em: 11/8/2017

\section{Sumário:}

1 Introdução. 2 Breves considerações sobre a crítica hermenêutica do Direito. 3 Ativismo judicial, judicialização da política e a crítica hermenêutica do Direito. 40 processo de impeachmente a decisão monocrática no MS № 34.441/DF. 4.1 Considerações iniciais. 4.2 A tese jurídico-filosófica da impetrante. 4.3 Os fundamentos da decisão monocrática do ministro Teori Zavascki. 5 Síntese dos argumentos. 6 Conclusão. 7 Referências. 


\section{INTRODUÇÃO}

O contexto jurídico e político brasileiro dos últimos dois anos tem sido marcado pela intensa atuação do Supremo Tribunal Federal (STF) - órgão de cúpula do poder Judiciário brasileiro com competência para zelar pelo cumprimento da Constituição de 1988 - em questôes políticas que envolvem os poderes Executivo e Legislativo. O problema do ativismo judicial no Supremo Tribunal Federal vem sendo percebido nos últimos anos pela comunidade acadêmica, especialmente após o início do processo de impeachment contra a ex-presidente Dilma Rousseff.

O Brasil vive, nos últimos meses, um contexto de incertezas políticas devido ao agravamento de uma crise de governabilidade que surgiu após a instauração do processo de impeachment na Câmara dos Deputados e pelo seu desfecho no Senado Federal, que culminou com a cassação do mandato da ex-presidente por crime de responsabilidade.

Isso posto, o presente artigo tem como objetivo analisar a decisão monocrática do ministro do STF Teori Zavascki na Medida Cautelar em Mandado de Segurança no 34.441 - DF, impetrado em setembro de 2016, logo após a condenaçáo da chefe do Executivo por crime de responsabilidade, que alegou violação aos direitos fundamentais do contraditório e da ampla defesa, bem como do devido processo legal durante o rito do processo no Congresso Nacional.

Por questóes processuais de reconvenção, a petição inicial do MS no 34.441/ DF solicitava que o processo fosse distribuído para ser relatado pelo ministro Teori Albino Zavascki, que era relator de outras duas açōes anteriores que versavam sobre atos decisórios da Câmara dos Deputados enquanto o processo de impeachment tramitava na respectiva casa legislativa. Sob a alegação de que não foram atendidos os princípios do contraditório e da ampla defesa devido às acusaçôes feitas em plenário e que não constavam da denúncia, a presidente Dilma Rousseff impetrou no STF o Mandado de Segurança no 32.193 - cujo relator foi o ministro Teori Albino Zavascki - no qual pedia a anulação da referida sessão plenária. O relator negou o pedido liminar por entender que se tratava de questáo interna do poder 
Legislativo. ${ }^{1}$ Assim como negara a referida ação, na Medida Cautelar em Mandado de Segurança no 34/441/DF, o ministro Teori Zavascki voltou a negar o pedido da ex-presidente.

Para identificar se a decisão monocrática é ou não uma decisão ativista e se foi dada uma resposta constitucionalmente adequada, faz-se necessário observarmos os argumentos da defesa da impetrante e da fundamentação utilizada pelo ministro Teori Zavascki para decidir a demanda.

Para tal, a Crítica Hermenêutica do Direito (CHD) desenvolvida pelo jusfilósofo Lênio Streck é o fundamento teórico e metodológico deste estudo para verificarmos se os atos interna corporis do poder Legislativo são ou não sindicáveis pela jurisdiçâo constitucional. Realizaremos uma pesquisa bibliográfica e documental sobre o tema para coletar as decisôes monocráticas nas Medidas Cautelares em Mandado de Segurança no 34.441/DF e no 34.193/DF. Concluímos que os atos administrativos do Congresso Nacional não podem sofrer uma espécie de "blindagem hermenêutica" e que o Estado Democrático de Direito assegura aos cidadãos que suas demandas possam ter respostas constitucionalmente adequadas.

\section{BREVES CONSIDERAÇÕES SOBRE A CRÍTICA HERMENÊUTICA DO DIREITO}

A Crítica Hermenêutica do Direito (CHD) é um movimento desenvolvido pelo jusfilósofo e professor da Universidade do Vale do Rio dos Sinos (Unisinos) Lênio Luiz Streck, cujo objetivo é possibilitar o diálogo entre o Direito e Filosofia. Para a jurista Clarissa Tassinari (2013, p. 12), uma das grandes expoentes da Crítica Hermenêutica do Direito, esta se trata de uma "teoria do direito construída sob os aportes paradigmáticos da Filosofia, possibilitando que se tenha uma crítica concepção do fenômeno jurídico, pois, em sua concepção, o questionamento típico da reflexão filosófica é essencial para a compreensão dos institutos jurídicos".

1 BRASIL. Supremo Tribunal Federal. Medida Cautelar em Mandado de Segurança no 34.193-DF. Impetrante: Presidente da República. Impetrados: Presidente da Câmara dos Deputados. Relator: Min. Teori Albino Zavascki. Brasília, 11 de maio de 2016. DJE no 97, 13/5/2016. 
Segundo Tassinari (2013, p. 12), o movimento de Lênio Streck visa a superar o positivismo jurídico por meio do estabelecimento de novas teorias sobre as fontes, normas e a interpretação do Direito, o que implica um novo olhar sobre o fenômeno jurídico. Qual seria, no entanto, o objetivo de se desenvolver uma nova teoria? Com o fracasso do positivismo jurídico na segunda metade do século 20 , o constitucionalismo que surgiu no segundo pós-guerra demandou uma nova teoria que envolvesse uma discussão dos fundamentos constitucionais do Direito. ${ }^{2}$

Dessa maneira, surgiram algumas posturas a partir dessa época com a pretensão de serem pós-positivistas (ou neoconstitucionalistas). Hans Kelsen, expoente do positivismo jurídico puro, ao separar a Moral da ciência jurídica para a elaboração de sua Teoria Pura do Direito, concebeu a decisão jurídica como um ato de vontade do julgador. Para Lênio Streck, a Moral e o Direito são cooriginárias, assim como entendem Jürgen Habermas e Ronald Dworkin, em contraponto ao que pensa o neoconstitucionalista Robert Alexy. ${ }^{3}$

Na concepção de Lênio Streck, a Moral institui a comunidade política, o que afasta a tese de Alexy, que trata a Moral como "ferramenta à disposição do julgador". Clarissa Tassinari (2013, p. 139-140) afirma que para Lênio Streck a tese de abertura dos princípios da Teoria da Argumentação Jurídica de Alexy é incompatível com o modelo pós-positivista de teoria do Direito por conceder maior discricionariedade aos juízes e tribunais, uma das características do positivismo jurídico.

As teorias pós-positivistas, no entanto, pensando que dessa forma superariam o positivismo de matriz kelseniana, atribuíram maior discricionariedade aos juízes e tribunais, entretanto, no entendimento de Lênio Streck, um dos elementos para a realização de uma teoria pós-positivista é o enfrentamento do problema do solipsismo jurídico que une todos os modelos de positivismo. ${ }^{4}$ Em que consiste, porém, o solipsismo jurídico? Para Lênio Streck, significa a maneira como o julgador

2 TASSINARI, Clarissa. Jurisdição e ativismo judicial: limites da atuação do Judiciário. Porto Alegre: Livraria do Advogado, 2013. p. 134.

3 Idem, p. 139.

4 STRECK, Lênio. O que é isto - decido conforme minha consciência? 4. ed. rev. Porto Alegre: Livraria do Advogado Editora, 2013. p. 105. 
decide conforme sua consciência, ${ }^{5}$ assunto que trataremos adiante. Por isso, para distinguir do neoconstitucionalismo, Lênio Streck denominou o constitucionalismo do pós-Segunda Guerra Mundial de Constitucionalismo Contemporâneo.

Na visão de Lênio Streck, como as teorias neoconstitucionalistas ainda não superaram o esquema sujeito-objeto, ele buscou fundamentar sua Crítica Hermenêutica do Direito a partir da obra de filósofos como Martin Heidegger, Hans-Georg Gadamer e Ernildo Stein e dos jusfilósofos Luís Alberto Warat e Ronald Dworkin. Primeiramente, ele parte da Filosofia hermenêutica de Heidegger, cujo modelo ontológico-linguístico superou o esquema sujeito-objeto. ${ }^{6}$ De acordo com Clarissa Tassinari (2014, p. 14), o método de Heidegger busca superar o velamento da questáo do ser, baseando-se num método binário de velamento e desvelamento.

Com a hermenêutica filosófica de Hans-Georg Gadamer, que expôs seu pensamento na obra Verdade e Método desenvolvido a partir dos estudos de seu orientador Martin Heidegger, o momento da interpretação do texto consiste no mesmo momento da aplicação que, para Clarissa Tassinari (2014, p. 14-15), é considerado um acontecimento unitário, que ele denominou de applicatio.

Antes de tudo, Clarissa Tassinari (2013, p. 13) apresenta alguns dos elementos da teoria de Lênio Streck. Primeiro, sob a influência de Luís Alberto Warat, ele busca romper com o dogmatismo por meio da confirmação de uma hermenêutica crítica na interpretação e aplicação do Direito. Segundo, com base na obra de Ernildo Stein, estudioso de Heidegger, ele construiu sua teoria sob os fundamentos da Filosofia hermenêutica deste e a hermenêutica filosófica de Gadamer, com o objetivo de romper a resistência filosófica que existe na comunidade jurídica brasileira. Com isso, ele pretende desenvolver uma Teoria da Decisão Judicial com base na proposta teórica de Ronald Dworkin, para conceber a tese do direito fundamental a respostas constitucionalmente adequadas como estrutura a partir do dever de fundamentar as decisões. ${ }^{7}$

\footnotetext{
5 Idem, p. 106.

${ }^{6}$ Ibidem, p. 118.

7 TASSINARI, Clarissa. O papel da Crítica hermenêutica do direito: sobre as relaçóes entre filosofia, teoria do direito e a atuação do judiciário. Fides, Natal, v. 5, n. 2, p. 7-24 (p. 13), jul./dez. 2014.
} 
Além do "novo modo de conceber o ato interpretativo", Clarissa Tassinari (2013, p. 15) nos mostra o segundo elemento da Teoria da Decisão Judicial, a responsabilidade política dos juízes. Lênio Streck baseia-se na ideia de integridade do Direito concebida por Ronald Dworkin (ideia de direito como um todo), que consiste na responsabilidade dos juízes perante a sociedade, devido ao fato de que o Estado Democrático de Direito tensionou as relaçôes entre os poderes na direçấo da jurisdiçāo. ${ }^{8}$

Dessa forma, Streck rompe com a tradição hermenêutica ao afastar as posturas objetivistas, como a vontade da lei, ao conceber o ato de aplicaçáo do Direito como atribuição de sentido ao texto (Sinngebung), ao invés de ser um procedimento de extração de sentido do texto (Auslegung). ${ }^{?}$

De acordo com Clarissa Tassinari (2013, p. 16), a responsabilidade política dos juízes desdobra-se no dever de fundamentação dos juízes, o terceiro elemento da Teoria da Decisão Judicial e derivado da Constituição de 1988. A Carta Magna instituiu no artigo 93, IX, que os juízes devem fundamentar suas decisóes. A referida norma apresenta-se no que Lênio Streck denominou de "respostas constitucionalmente adequadas", o quarto elemento da Teoria. Com isso, na opinião de Tassinari (2013, p. 16), a discricionariedade é superada, rompendo com as estruturas solipsistas (fundadas na vontade do sujeito) que fragilizam a estrutura do texto constitucional. Para a autora, o posicionamento de Lênio Streck apresenta-se indispensável à legitimidade da jurisdição. ${ }^{10}$

A partir dessa sucinta explanaçáo, concluímos que a Crítica Hermenêutica do Direito revela-se essencial para o estudo do problema do ativismo judicial, que será visto a seguir e como método para a realização dos objetivos do presente artigo.

\section{ATIVISMO JUDICIAL, JUDICIALIZAÇÃO DA POLÍTICA E A CRÍTICA HERMENÊUTICA DO DIREITO}

A Constituição de 1988 consagrou um conjunto de direitos fundamentais-sociais conquistados após o fim do regime militar que se iniciou em 1964. Para Clarissa Tassinari (2013, p. 24), no contexto brasileiro, apenas com o fim da ditadura

\footnotetext{
8 Idem, p. 15.

9 Ibidem, p. 15.

${ }^{10}$ Ibidem, p. 16.
} 
militar foi que se criou um ambiente propício para o desenvolvimento da ideia de concretização dos direitos dos cidadáos. Com a falta de empenho dos poderes Executivo e Legislativo para instituir e assegurar esses direitos, o poder Judiciário passa a atuar em questóes político-sociais por meio de duas maneiras distintas: o ativismo judicial e a judicialização da política. ${ }^{11}$

Em um artigo no qual fazem uma análise da decisão do ministro do STF Luís Roberto Barroso no MS 32.326/DF, Streck, Tassinari e Lepper (2015, p. 55) afirmam que o ponto de partida para se fazer uma distinção entre judicialização da política e ativismo judicial é uma citação de Friedrich Müller (2003 apud STRECK; TASSINARI; LEPPER, 2015) ao afirmar que o "Direito constitucional é o direito do político" e que "insistir nisso, não tem relação nenhuma com o 'decisionismo"”. Ele reforça a vinculação entre Direito e política.

Nessa seara, segundo os autores, o que leva à confusão entre judicialização da política e ativismo judicial é o fato de que, quando a política é considerada um "fator externo" de incidência eventual no âmbito jurídico, gera posicionamentos opostos, pois ela passa de "mola propulsora" para a construção do conteúdo jurídico-constitucional para uma espécie de "argumento corretivo" do Direito, o que a caracteriza como "predador externo da autonomia do Direito". ${ }^{12}$

Nesse caso, a judicialização da política apresenta-se como uma questão social, derivada de fatos alheios à jurisdição e que tem, como ponto de partida, um maior reconhecimento de direitos, devido à ineficiência do poder estatal em instituí-los, o que permite o aumento do número de litígios. Sua diminuição depende de medidas geradas pelo compromisso de todos os poderes e não apenas do Judiciário. ${ }^{13}$

\footnotetext{
${ }^{11}$ STRECK, Lênio. TASSINARI, Clarissa; LEPPER, Adriano Obach. O problema do ativismo judicial: uma análise do caso MS3326. Revista Brasileira de Políticas Públicas, Brasília, v. 5, Número Especial, p. 51-61, 2015.

${ }^{12}$ Idem, p. 55.

${ }^{13}$ Ibidem, p. 55.
} 
Lênio Streck alerta para o problema de se colocar o ativismo e a judicialização da política no mesmo patamar. Segundo o autor, o problema do ativismo decorre da construção de uma linguagem privada à margem de uma linguagem pública, quando os juízes e tribunais demonstram seus comportamentos pessoais nas decisóes judiciais. ${ }^{14}$ Trata-se de um ato de vontade do julgador.

O ativismo está atrelado à maneira como o Judiciário oferece uma solução à demanda objeto da judicializaçáo, quando a vontade do julgador substitui o debate político. Nesse sentido, de uma questão que sofreu judicialização pode-se ter uma resposta ativista, ou de uma questão ativista pode-se ter uma resposta constitucionalmente adequada. ${ }^{15}$ Nas palavras de Lênio Streck:

Hermeneuticamente, é possível necessário estabelecer uma fronteira entre judicialização da política e ativismo judicial, em que o primeiro se apresente de forma inexorável ao paradigma vigente e o outro como danoso e prejudicial (2014, p. 711).

Nos moldes da Crítica Hermenêutica do Direito Lênio Streck (2016) apresenta algumas posturas ativistas, por exemplo, decisóes em que haja a substituição de argumentos jurídicos por argumentos morais. Decisóes contra legem, nas quais o juiz substitui os juízos pessoais do constituinte ou do legislador ordinário pelos seus próprios juízos também se configura como uma conduta ativista. Streck (2016) observa que textos que dão margem ao livre convencimento do juiz, à ponderação de valores, etc., incentivam o ativismo judicial. ${ }^{16}$

Lênio Streck (2016) exemplifica algumas características de uma decisão judicial com relação à vontade do julgador: "decido conforme à consciência"; "decido conforme o justo"; "decido e depois procuro um fundamento"; "decido conforme o clamor da sociedade". Por vezes, segundo Streck (2016), percebe-se

\footnotetext{
${ }^{14}$ STRECK, Lênio. O Rubicão e os quatro ovos do condor: de novo, o que é ativismo? Consultor Jurídico, 7 de janeiro de 2016. Disponível em: <http://www.conjur.com.br/2016-jan-07/senso-incomum-rubicao-quatro-ovos-condor-ativismo>. Acesso em: 29 dez. 2016.

${ }^{15}$ Idem, p. 2.

${ }^{16}$ Ibidem, p. 2.
} 
na jurisprudência dos tribunais decisóes nas quais se apela à letra da lei e, em outras, utilizam-se de princípios para justificar a primazia desses sobre a lei aprovada democraticamente pelo Legislativo. ${ }^{17}$

$\mathrm{O}$ autor nos apresenta uma pergunta fundamental para identificar se uma decisão é ou não ativista: "Tal decisão, nos moldes em que foi proferida, pode ser repetida em situaçôes similares?" Se a resposta é "não", então existem fortes indícios de ativismo judicial. ${ }^{18}$ De acordo com Clarissa Tassinari (2013, p. 19) pode-se tratar de uma postura ativista quando se percebe, a partir das decisóes proferidas, a configuraçáo de um poder Judiciário dotado de supremacia, com competências que lhe não foram reconhecidas na Constituição.

Por isso, no entendimento de Lênio Streck (2013, p. 107), sob pena de ferir o "princípio democrático", as decisóes não podem depender da consciência do juiz ou do livre convencimento. Em sua concepção, decidir é diferente de escolher e existe um termo jurídico que define a escolha: discricionariedade e, quiçá, arbitrariedade. A decisão não depende de uma escolha, mas sim do comprometimento com algo que se antecipa. Esse algo que se antecipa é a compreensão daquilo que a "comunidade política constrói como direito". ${ }^{19}$ Tal construção não é a soma de várias partes, mas sim um todo que se define como a melhor interpretaçáo. Para o autor, toda decisão deve se fundar num compromisso, que passa pela reconstrução da história institucional do Direito. ${ }^{20}$

Nesse sentido, o autor entende que a discricionariedade, o ativismo judicial e o positivismo jurídico sáo faces do subjetivismo que precisam ser combatidos. Esse combate é um "compromisso com a democracia e com a legislação democraticamente construída”. ${ }^{21}$

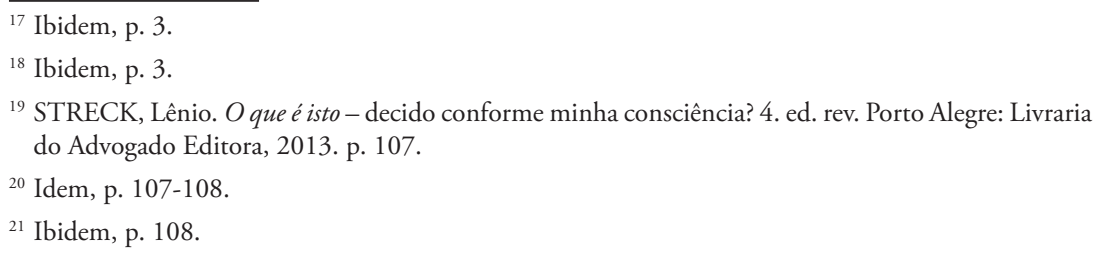


Então, Lênio Streck (2013, p. 109) recorre a Dworkin e Gadamer pois, na sua compreensão, eles buscam, ao seu modo, controlar esse subjetivismo a partir da tradição, do círculo hermenêutico, do respeito à coerência e integridade do Direito, pois são teorias antimetafísicas que rejeitam o dualismo que a metafísica nos legou desde Platão. Segundo Streck (2013, p. 110), por meio das teorias de Gadamer e Dworkin é possível distinguir boas e más decisóes, pois os juízes devem aceitar uma restrição independente e superior, que decorre da integridade das decisóes que proferem.

Em resumo, no entendimento de Clarissa Tassinari, ${ }^{22}$ o ativismo judicial fragiliza a autonomia do Direito. Feitas essas consideraçóes que servirão de base teórica e metodológica para nossa análise, deparamo-nos com algumas indagaçóes. Em primeiro lugar, a decisão monocrática do ministro Teori Zavascki no MS. 34.441/DF foi uma decisão ativista? A depender da resposta, analisaremos a legitimidade da respectiva decisão no sistema jurídico e político brasileiro com base nos pressupostos teóricos da Crítica Hermenêutica do Direito para, em seguida, constatar se o magistrado proferiu uma resposta constitucionalmente adequada.

Antes disso, apresentaremos a seguir os argumentos da defesa da ex-presidente Dilma Rousseff no MS. 34.44 - DF, bem como os fundamentos que levaram o ministro Teori Zavascki a proferir sua decisão monocrática.

\section{PROCESSO DE IMPEACHMENT E A DECISÃO MONOCRÁTICA NO MS No 34.441/DF}

\subsection{CONSIDERAÇÕES INICIAIS}

No dia 29 de setembro de 2016, o advogado da ex-presidente Dilma Rousseff impetrou um mandado de segurança no Supremo Tribunal Federal cujo pedido principal consistia na anulação da Resolução n. 35/16 do Senado Federal. $\mathrm{O}$ ato normativo do Senado dispunha sobre a perda do mandato da presidente, ou

${ }^{22}$ TASSINARI, Clarissa. Jurisdição e ativismo judicial: limites da atuação do judiciário. Porto Alegre: Livraria do Advogado, 2013. 
seja, a sanção estipulada para a punição da prática do crime de responsabilidade apontado na denúncia n. 01/2015. O mandado de segurança foi impetrado em face do presidente do Senado Federal, Renan Calheiros (PMDB-AL), e do presidente do Supremo Tribunal Federal, ministro Ricardo Lewandowski, responsáveis pela edição da resolução.

A ação visava a anular a decisão do Senado em razão, segundo a impetrante, da ausência de pressupostos jurídicos indispensáveis para que a instância julgadora pudesse deliberar sobre o real cometimento de crime de responsabilidade, além de que não foram observados os princípios constitucionais do contraditório e da ampla defesa, bem como o do devido processo legal. Dessa maneira, argumentou a impetrante, representada legalmente em juízo pelo seu procurador, o ex-ministro da Justiça e Advogado-Geral da União, José Eduardo Cardozo, que o processo de impeachment no qual foi ré se configura como inconstitucional e abusivo.

Por questôes processuais de reconvenção, a petição inicial do MS no 34.441/ DF solicitava que o processo fosse distribuído para ser relatado pelo ministro Teori Albino Zavascki, que era relator de outras duas açóes anteriores que versavam sobre atos decisórios da Câmara dos Deputados enquanto o processo de impeachment tramitava na respectiva casa legislativa, sob a alegação de que não foram atendidos os princípios do contraditório e da ampla defesa.

\subsection{A TESE JURÍDICO-FILOSÓFICA DA IMPETRANTE}

Os argumentos da petição inicial construídos pelo advogado e ex-ministro da Justiça e Advogado-Geral da Uniáo, José Eduardo Cardozo, são apresentados pelo ministro Teori Zavascki em sua decisão monocrática. De acordo com a impetrante,

(...) a Constituição de 1988 teria consagrado o Estado Democrático de Direito de perfil presidencialista, sistema de governo mantido por decisão plebiscitária de 21 de abril de 1993, com todas as características originais desse modelo, entre as quais o restritivo e excepcional campo de responsabilização política dessa autoridade, cuja proteção seria elementar para a garantia da estabilidade institucional do país (Medida Cautelar em Mandado de Segurança no 34.441DF, 2016, p. 7). 
Com isso, a impetrante quer afirmar que a condenação de um presidente da República não pode se dar de maneira que não se atenda a requisitos constitucionais que assegurem que a decisão de afastá-lo não acarrete uma crise institucional no país, que já vinha sofrendo as consequências do processo desde a aceitação da denúncia, em dezembro de 2015.

Como o advogado José Eduardo Cardozo pede a suspensão do MS n ${ }^{\circ}$ 34.193/DF por questôes processuais de continência, ele reitera o conteúdo da primeira ação ao afirmar que a falta de lógica da decisão de Eduardo Cunha quando admitiu parcialmente a denúncia na Câmara dos Deputados sem qualquer demonstração de indícios de autoria corroboraria a presunção de ocorrência de desvio de finalidade. Outrossim, alega o advogado que, durante a sessão especial da Câmara dos Deputados ocorrida no dia 17 de abril de 2016, os parlamentares mencionaram fatos alheios à denúncia e não foi permitido à defesa se manifestar sobre as respectivas acusaçóes no momento oportuno. ${ }^{23}$

A principal tese levantada diz respeito à apreciação dos atos do poder Legislativo, no caso o Senado Federal, pela jurisdiçáo constitucional. Como o Senado Federal estaria exercendo uma atividade estatal atípica, sua natureza se adequaria ao perfil administrativo devido à ausência de aptidáo para gerar coisa julgada, característica singular da atividade judiciária. De acordo com a impetrante, não existem fundamentos jurídicos-políticos no Estado de Direito para que as decisões proferidas no Senado Federal sejam materialmente imutáveis. ${ }^{24}$

Como exemplo de apreciação dos atos do Senado Federal durante um processo de impeachment, a defesa levantou o precedente do caso "Collor" (1992), cuja decisáo do Senado foi revisada posteriormente pelo STF. Por isso, afirma a impetrante:

${ }^{23}$ BRASIL. Supremo Tribunal Federal. Medida Cautelar em Mandado de Segurança no 34.441-DF. Impetrante: Dilma Vana Rousseff. Impetrados: Presidente do Senado Federal e Presidente do Supremo Tribunal Federal. Relator: Min. Teori Albino Zavascki. Brasília, 29 de setembro de 2016. DJE no 226, 21/10/2016.

${ }^{24}$ Idem, p. 8. 
A atuação do Supremo Tribunal Federal, em especial para garantir a não ultrapassagem dos limites da moldura constitucional do impeachment, seria essencial para evitar que o instituto sucumbisse ao puro exercício do poder, assegurando o Estado Democrático de Direito em momentos de crise política (Medida Cautelar em Mandado de Segurança no 34.441-DF, 2016, p. 11).

Devido à natureza híbrida dos crimes de responsabilidade - jurídica e política - argumenta a impetrante que deveriam ser verificados pressupostos jurídicos mínimos, como a comprovação probatória, o devido processo legal e a imparcialidade dos julgadores, como são verificados num processo comum no poder Judiciário. Dessa maneira, a existência desses pressupostos jurídicos faz-se imprescindível pelo fato de não ser permitido fazer um juízo acerca da existência do fato delituoso apenas com base em critérios políticos e sim com base em hipóteses legais. ${ }^{25}$

Quanto à ontologia dos crimes de responsabilidade, a impetrante aduz que somente poderiam ser imputados à presidente da República os atos praticados por ela no decurso do seu mandato (artigo $86, \$ 4^{\circ} \mathrm{da} C F / 88$ ) e náo por seus subordinados, sob pena de contrariar o artigo 85 da Constituição de 1988 e o princípio da culpabilidade (p. 9). Ademais, sob pena de violar o princípio constitucional da irretroatividade da lei penal (artigo 5º, XL da CF/88), náo se admitiria retroagir uma interpretação para quem se comportou de acordo com o entendimento firmado à época pelo Tribunal de Contas da União. ${ }^{26}$

Para a impetrante, o princípio da imparcialidade estaria sendo violado quando da divulgaçáo antecipada dos votos pelos senadores pela demonstraçáo da formação de "placares" pela imprensa nacional antes do fim da instrução processual, bem como as imposiçóes partidárias em relação aos votos dos parlamentares que, segundo a tese apresentada na petição inicial, foram toleradas tanto na Câmara em que foi realizado o juízo de admissibilidade - quanto no Senado - no qual foi analisado o mérito. ${ }^{27}$

\footnotetext{
${ }^{25}$ Ibidem, p. 8-9.

${ }^{26}$ Ibidem, p. 9.

${ }^{27}$ Ibidem, p. 32.
} 
Com isso, alega a impetrante que o princípio da imparcialidade é mitigado de forma inevitável em processos como os de impeachment, tendo em vista que ele não pode ser convertido em "princípio da parcialidade", como entendeu a Corte Interamericana de Direitos Humanos nos casos do Tribunal Constitucional do Peru contra o Peru (2001) e do Tribunal Constitucional do Equador contra o Equador (2013). ${ }^{28}$

Como a discussão acerca da assinatura de créditos girava em torno da configuração ou não de crime de responsabilidade, para comprovar a tese de que náo foi a atendida regra constitucional do in dubio pro reu, a impetrante relata os casos do senador Cristóvam Buarque (PPS-DF) que, não considerando o referido princípio constitucional, declarou ter escolhido "a melhor interpretação jurídica para o país”, e dos senadores Telmário Mota (PDT-RR) e Acir Gurgacz (PDT-RO), que admitiram a inexistência de crime de responsabilidade, embora tenham votado a favor da condenação da presidente. ${ }^{29}$

\subsection{OS FUNDAMENTOS DA DECISÃO MONOCRÁTICA DO MINISTRO TEORI ZAVASCKI}

$\mathrm{Na}$ segunda parte da decisão, após expor as razóes do pedido, o ministro Teori Zavascki argumenta que uma das circunstâncias que limita o controle jurisdicional do processo de impeachment é a natureza da demanda, ou seja, o fato de o processo tratar de crime de responsabilidade contra o presidente da República não é da competência do Supremo Tribunal Federal, e sim do poder Legislativo, de acordo com o artigo 86 da Constituiçáo de 1988. Nas palavras do relator:

O juiz constitucional da matéria é o Senado Federal, que, previamente autorizado pela Câmara dos Deputados, assume o papel de tribunal de instância definitiva, cuja decisão de mérito é insuscetível de reexame, mesmo pelo Supremo Tribunal Federal (Medida Cautelar em Mandado de Segurança no 34.441-DF, 2016, p. 35).

\footnotetext{
${ }^{28}$ Ibidem, p. 16.

${ }^{29}$ Ibidem, p. 34.
} 
Nesses termos, o ministro Teori Zavascki assegura que uma decisão acerca do mérito da decisão transformaria em letra morta o artigo 86 da Constituição de 1988, que elenca os crimes de responsabilidade cometidos pelo presidente da República. Como o julgamento é feito por juízes investidos na condição de políticos, seus votos são conduzidos por valores de natureza política inspirados em valor $\mathrm{e}$ motivaçóes diferentes dos que seriam utilizados pelo poder Judiciário. ${ }^{30}$

O relator afirma que o MS no 34.441 - DF trata-se da ação mais atípica impetrada pela autora, tanto pelo número de pedidos e pelo conteúdo das teses levantadas, quanto pelo resultado que se pretende obter. Pelo fato de ser uma ação que impóe juízos inéditos na experiência jurisprudencial brasileira, entende o ministro relator que ela merece uma delicada avaliação no que diz respeito à cláusula da separação dos poderes. ${ }^{31}$

No entendimento de Zavascki, a ação impetrada por Dilma Rousseff revela-se um tema complexo sobre os limites da intervenção judicial e que envolve as mais acirradas disputas doutrinárias, além do anacronismo da legislação que versa sobre os crimes de responsabilidade (Lei $n^{\circ} 1.079 / 50$ ) que, segundo ele, segue o mesmo entendimento firmado pelos membros da Corte na ADPF $378 .{ }^{32}$ De acordo com Teori Zavascki:

É preciso também considerar que, enquanto a possibilidade de exame de parte das impugnaçóes enunciadas neste mandado de segurança é altamente controversa, dúvidas não há sobre as avassaladoras consequências que uma intervenção judicial volúvel poderia gerar no ambiente institucional do País, que atravessa momentos já táo dramáticos do seu destino coletivo (Medida Cautelar em Mandado de Segurança no 34.441-DF, 2016, p. 37).

\footnotetext{
${ }^{30}$ BRASIL. Supremo Tribunal Federal. Medida Cautelar em Mandado de Segurança no 34.441-DF. Impetrante: Dilma Vana Rousseff. Impetrados: Presidente do Senado Federal e Presidente do Supremo Tribunal Federal. Relator: Min. Teori Albino Zavascki. Brasília, 29 de setembro de 2016. DJE n 226, 21/10/2016. (p. 36).

${ }^{31}$ Idem, p. 36.

${ }^{32}$ Ibidem, p. 36.
} 
Para Teori Zavascki, apenas uma demonstração cabal da indispensável prevençáo dos danos à democracia e, consequentemente, ao Estado de Direito, justificariam o deferimento de um juízo imediato às questóes demandadas pela impetrante de maneira antecipada, ou seja, por medida cautelar. Na petição inicial, a impetrante apenas argumenta que o país náo pode continuar a ser governado por quem náo foi eleito e que o risco que demanda uma medida cautelar diz respeito apenas às medidas que seriam instituídas por quem governa de forma ilegítima, mudanças estas que não poderiam ser desfeitas.

Segundo o relator, o argumento da impetrante é contraditório em virtude de que o vice-presidente é eleito com a presidente com ele registrado, nos termos do artigo $77, \S 1^{\circ}$ da Constituição de 1988 e que ele tem legitimidade para a sucessão presidencial em caso de vacância, nos termos do artigo 79 da Carta Magna. ${ }^{33}$

Como, no entendimento do ministro relator, não foram demonstrados "riscos às instituições republicanas, ao Estado Democrático de Direito ou a ordem constitucional", o que justificaria a atuação imediata do Supremo Tribunal Federal, ele indeferiu a liminar..$^{34}$

\section{SÍNTESE DOS ARGUMENTOS}

Com base nos pressupostos teóricos da Crítica Hermenêutica do Direito e nos argumentos apresentados tanto pela defesa da ex-presidente Dilma Rousseff como pelo ministro Teori Zavascki em sua decisão monocrática, o primeiro questionamento a ser respondido diz respeito à apreciação dos atos interna corporis do poder Legislativo, em especial a Resolução no $25 / 16$, que resultou na sentença que culminou no afastamento definitivo da chefe do Executivo.

Segundo Lênio Streck (2014, p. 708), o STF vem tomando posição incompatível com o Estado Democrático de Direito e com a ideia de controle de constitucionalidade em relação à análise dos atos ditos interna corporis do Congresso Nacional. Em seu posicionamento, ele lembra que o mais antigo julgado sobre o tema no STF é o do MS. no 20.247 de 1980, cujo relator foi o ministro Moreira Alves. Na ação era discutido um ato da Mesa do Senado Federal. Entre vários julgados que o

\footnotetext{
${ }^{33}$ Ibidem, p. 37-38.

${ }^{34}$ Ibidem, p. 38.
} 
autor apresenta, no MS 26.062, o STF decidiu apreciar o ato do Legislativo apenas numa análise formal dos requisitos procedimentais exigidos pela Constituição de 1988. Segundo Streck, não concordou com a decisão por entender que:

Cindir exigências formais de materiais é impossível no paradigma filosófico atual, além de incompatível com o Estado Democrático de Direito, mitigando a supremacia da Constituição, o que justificaria a não incidência de várias de suas previsóes em funçấo de uma pretensa hegemonia da cláusula da independência dos poderes (2014, p. 709).

Um dos mais recentes julgados é o MS no 25.588, em que o relator, o ministro Menezes Direito, não admitiu a sindicabilidade, arguindo a violação da independência dos poderes, por interpretar a questão à luz do Regimento Interno da Câmara dos Deputados.

Nesse sentido, para Lênio Streck (2014, p. 709), o STF admitiu que tais atos não seriam passíveis de apreciação judicial, criando assim uma "blindagem hermenêutica" ou um caso de "imunidade à jurisdição". Em sendo os atos interna corporis apenas atos administrativos, o jusfilósofo entende que o posicionamento do STF é primitivo por considerar que os referidos atos não estáo sujeitos à sindicabilidade pela jurisdição constitucional. Em suas palavras:

Contemporaneamente, não parece admissível a "blindagem" de atos do Parlamento, em que nenhuma norma jurídica está imune à Constituição. Tratando-se de violação da Constituição, nenhum ato do Legislativo ou de qualquer outro poder ou instituição pode estar a salvo da sindicabilidade constitucional, e isso independe de se assumir uma postura procedimentalista ou substancialista (STRECK, 2014, p. 711).

Isso posto, segundo Lênio Streck (2013, 2014), o Estado Democrático de Direito, em seu sentido hermenêutico, se traduz em uma "blindagem" a ativismos e decisionismos, ou seja, "nenhum ato do poder Executivo ou Legislativo está imune à sindicabilidade de cariz constitucional. .5 "

35 STRECK, Lênio Luiz. Jurisdição constitucional e decisão jurídica. 4. ed. São Paulo: Editora Revista dos Tribunais, 2014. p. 151.

O que é isto - decido conforme minha consciência? 4. ed. rev. Porto Alegre: Livraria do Advogado Editora, 2013. p. 113. 
A defesa da ex-presidente Dilma Rousseff advoga que o ato administrativo do presidente da Câmara ao acatar a denúncia estava eivado de desvio de finalidade. Em que consiste esse desvio, no entanto? Segundo a impetrante, Eduardo Cunha solicitou apoio da bancada do Partido dos Trabalhadores na Comissão de Ética da Câmara em troca de não aceitar a peça denunciatória impetrada meses antes.

De acordo com uma análise da decisão monocrática do ministro Teori Zavascki acerca do tema de desvio de finalidade no MS. 34.193, os juristas Alexandre Gustavo de Melo Franco Bahia, Diogo Bacha e Silva e Marcelo Cattoni de Oliveira (2016) constataram que o processo de impeachment estaria contaminado pelo desvio de finalidade, uma vez que o ex-presidente da Câmara, Eduardo Cunha, havia sido suspenso de suas funçóes. E como chegaram a essa conclusão? Eles argumentam que se um ato é praticado buscando atingir um fim contrário ao objetivo previsto na Constituição ou na legislação ordinária, então este ato está eivado pelo desvio de finalidade ou de poder. ${ }^{36}$

Em sua decisão monocrática, o ministro Teori Zavascki entendeu que para identificar o desvio de finalidade seria necessário imergir no plano subjetivo do agente público que praticou o ato, o que se torna inviável tendo em vista que o ato contestado representa a vontade de 370 parlamentares. Com isso, os juristas entenderam que a decisão negou o controle judicial do desvio de finalidade dos atos públicos sob o argumento de se tratar de questáo subjetiva. Para eles, o próprio STF, em seus julgados sobre nepotismo cruzado, observou apenas o caráter objetivo do ato, bem como os juristas têm escrito que ao desvio de poder prescinde à análise subjetiva do agente público. ${ }^{37}$

Dessa maneira, eles chegam a fazer o seguinte questionamento: Decisóes sobre o cumprimento da Constituiçáo e das leis tratando do devido processo legal podem ser tomadas sem qualquer controle judicial? Concluiu-se que a decisáo do ministro Teori Zavascki afasta da jurisdição constitucional a análise da moralidade e da finalidade dos atos administrativos. ${ }^{38} \mathrm{E}$ como pensar em ato interna corporis

\footnotetext{
${ }^{36}$ BAHIA, Alexandre G. M. F. M.; BACHA E SILVA, Diogo; CATTONI DE OLIVEIRA, Marcelo A. "Legitimação normalizadora" do impeachment pelo Supremo Tribunal Federal? Empório do Direito, 16, p. 2, maio 2016.

${ }^{37}$ Idem, p. 2.

${ }^{38}$ Ibidem, p. 3
} 
se o processo de impeachment envolve o nosso sistema político-democrático e a própria estrutura do nosso sistema presidencialista de governo e, no fundo, envolve a autonomia pública de todos os cidadãos de nossa comunidade política? - questionam os autores.

A resposta é que com a ADPF $378^{39}$ o STF deu uma demonstração de que o rito do processo de impeachment não é uma questáo tão somente política, mas suscetível do controle jurisdicional. ${ }^{40}$ Por fim, Bahia, Bacha e Silva e Cattoni de Oliveira (2016) concluem que a análise das decisôes proferidas na Corte Suprema devido a sua a omissão jurisdicional em seu dever de garantir a Constituição e o Estado Democrático de Direito em tempos de crise caracterizam, no seu ponto de vista, uma "legitimação normalizadora" do processo de impeachment. ${ }^{41}$

Ao indeferir a medida cautelar, o ministro Teori Zavascki aduziu que o MS 34.441 - DF merecia uma delicada avaliação em relação à cláusula da independência dos poderes. Tal argumentação não poderia servir de fundamento para adiar a análise do mérito da questáo pelo plenário da Corte Suprema tendo em vista que o vice-presidente Michel Temer assumiu o cargo de presidente da República e, quando de uma futura decisão favorável à Dilma Rousseff, esta não poderia mais usufruir do tempo de mandato decorrido.

Nesse sentido, seguimos o entendimento de Lênio Streck, Clarissa Tassinari e Adriano Obach Lepper (2015) ao defenderem que o argumento que fundamenta uma decisão judicial deve ser jurídico, e não moral ou político, ou seja, a necessidade de se decidir com base em argumentos jurídicos é a garantia de cumprimento e respeito à Constituição. ${ }^{42}$

\footnotetext{
${ }^{39}$ Trata-se da Arguição de Descumprimento de Preceito Fundamental no 378 transitada em julgado no dia 13/10/2016, cujo relator foi o ministro Edson Fachin e que definiu a legitimidade constitucional do rito do processo de impeachment no Congresso Nacional previsto na Lei no 1.079/50.

${ }^{40}$ BAHIA, Alexandre G. M. F. M.; BACHA E SILVA, Diogo; CATTONI DE OLIVEIRA, Marcelo A. "Legitimação normalizadora" do impeachment pelo Supremo Tribunal Federal? Empório do Direito, 16, p. 3, maio 2016.

${ }^{41}$ Ibidem, p. 1.

${ }^{42}$ STRECK, Lênio Luiz; TASSINARI, Clarissa; LEPPER, Adriano Obach. O problema do ativismo judicial: uma análise do caso MS3326. Revista Brasileira de Políticas Públicas, Brasília, v. 5, Número Especial, p. 54-59, 2015.
} 


\section{CONCLUSÃO}

A Constituição de 1988 constituiu o Estado Democrático de Direito que, com sua carga de princípios, assegura a força normativa de seu texto que uma nova hermenêutica para assegurar que as decisóes judiciais possam estar assentadas sob pressupostos democráticos, como bem entende a jurista Clarissa Tassinari. Com o advento da Crítica Hermenêutica do Direito (CHD) desenvolvida por Lênio Streck, à comunidade acadêmica é possibilitado debruçar-se sobre o problema do ativismo judicial antes de buscar respostas. Ademais, trata-se de um instrumento teórico e metodológico que serve para a análise das decisóes judiciais em sede de jurisdição constitucional no intuito de verificar se elas estáo garantindo aos cidadáos respostas constitucionalmente adequadas as suas demandas.

Com isso, embora na petição inicial o advogado José Eduardo Cardozo admita que o controle jurisdicional não devia adentrar o mérito do processo, com base na Crítica Hermenêutica do Direito entendemos que, como a decisão do Senado Federal não seguiu a devida interpretação hermenêutica do texto constitucional, poderia ser apreciada pelo Supremo Tribunal Federal para que, como guardião precípuo da Constituição de 1988, pudesse garantir os direitos fundamentais ao devido processo legal e ao contraditório e ampla defesa à impetrante que se sentiu prejudicada.

Dessa maneira, foi possível constatar ao longo dessa explanação que a decisão monocrática do ministro Teori Zavascki foi tomada por um ato de vontade do julgador, que decidiu com base em argumentos políticos e não jurídicos, o que viola os pressupostos democráticos instituídos pela Constituição de 1988. A decisão não poderia ser repetida em casos semelhantes, pois apresenta diversas características de ativismo judicial. Ademais, não pode ser considerada uma resposta adequada à Constituição, pois os fundamentos basearam-se nos preceitos constitucionais que garantem que os atos interna corporis do poder Legislativo, como atos administrativos, são sindicáveis ao controle jurisdicional quando violarem o texto constitucional, bem como as regras do jogo democrático. 


\section{REFERÊNCIAS}

BAHIA, Alexandre G. M. F. M.; BACHA E SILVA, Diogo; CATTONI DE OLIVEIRA, Marcelo A. "Legitimação normalizadora" do impeachment pelo Supremo Tribunal Federal? Empório do Direito, 16 maio 2016. 2016. Disponível em: <http://emporiododireito.com. br/legitimacao-normalizadora-do-impeachment/>. Acesso em: 28 dez. 2016.

BRASIL. Constituição (1988). Constituição da República Federativa do Brasil. Diário Oficial da União, 5. out. 1988. Disponível em: <http://www.planalto.gov.br/ccivil_03/constituicao/ constituicaocompilado.htm>. Acesso em: 29 dez. 2016.

. Supremo Tribunal Federal. Medida Cautelar em Mandado de Segurança no 34.193DF. Impetrante: Presidente da República. Impetrados: Presidente da Câmara dos Deputados. Relator: Min. Teori Albino Zavascki. Brasília, 11 de maio de 2016. DJE no 97, 13/05/2016.

. Supremo Tribunal Federal. Medida Cautelar em Mandado de Segurança no 34.441-DF. Impetrante: Dilma Vana Rousseff. Impetrados: Presidente do Senado Federal e Presidente do Supremo Tribunal Federal. Relator: Min. Teori Albino Zavascki. Brasília, 29 de setembro de 2016. DJE no 226, 21/10/2016.

- Supremo Tribunal Federal. Acórdão. Medida Cautelar na Arguição de Descumprimento de Preceito Fundamental no 378 - DF. Requerente: Partido Comunista do Brasil. Intimados: Presidente da República e Congresso Nacional. Relator: Min. Edson Fachin. Brasília, 16 de dezembro de 2015, DJE no 255, 17/12/2016.

STRECK, Lênio Luiz. Jurisdição Constitucional e Decisão Jurídica. 4. ed. São Paulo: Editora Revista dos Tribunais, 2014.

. TASSINARI, Clarissa; LEPPER, Adriano Obach. O problema do ativismo judicial: uma análise do caso MS3326. Revista Brasileira de Políticas Públicas, Brasília, v. 5, Número Especial, p. 51-61, 2015.

. O que é isto - decido conforme minha consciência? 4. ed. rev. Porto Alegre: Livraria do Advogado Editora, 2013.

- O Rubicão e os quatro ovos do condor: de novo, o que é ativismo? Consultor Jurídico, São Paulo, jan. 2016. 2016. Disponível em: <http://www.conjur.com.br/2016-jan-07/senso-incomum-rubicao-quatro-ovos-condor-ativismo>. Acesso em: 29 dez. 2016.

TASSINARI, Clarissa. Jurisdição e ativismo judicial: limites da atuação do judiciário. Porto Alegre: Livraria do Advogado, 2013.

. O papel da crítica hermenêutica do direito: sobre as relações entre filosofia, teoria do direito e a atuação do judiciário. Fides, Natal, v. 5, n. 2, p. 7-24, jul./dez. 2014.

ZAVASCKI, Teori A. Eficácia das sentenças na jurisdição constitucional. 2000. Dissertação (Mestrado em Direito) - UFRGS, Porto Alegre, 2000. 